\title{
Three cases of alpha-1-antitrypsin deficiency in the elderly
}

\author{
C.I.A. Jack and C.C. Evans \\ Royal Liverpool Hospital, Prescot Road, Liverpool, UK
}

\begin{abstract}
Summary: We report three elderly patients who presented with increasing dyspnoea on exertion and radiological evidence of basal bullous emphysema. On further investigation they were found to have alpha-1-antitrypsin deficiency.

We emphasize that alpha-1-antitrypsin deficiency can present much later than is usually the case especially if the patient is a life-long non-smoker.
\end{abstract}

\section{Introduction}

We report three cases of alpha-1-antitrypsin deficiency presenting for the first time in elderly patients (average 72 years) as chronic airflow limitation. All three patients were life-long nonsmokers, and had no relevant family history or evidence of hepatic involvement.

Previous reports have emphasized early presentation with emphysema in young or middle-aged adults, cryptogenic cirrhosis in children and non-B chronic active hepatitis in young adults. ${ }^{1,2}$ There is also an association between rheumatoid arthritis and reduced $\alpha$-1-antitrypsin levels $s^{3,4}$ and case reports linking uveitis, thyroiditis, vasculitis and glomerulonephritis with $\alpha-1$-antitrypsin deficiency. ${ }^{5-7}$ We believe that alpha-1-antitrypsin deficiency should be sought in patients with clinical and radiological features of emphysema irrespective of age so that advice may be offered to other family members.

\section{Case reports}

\section{Case one}

A 69 year old female retired accounts officer presented with an 8-year history of increasing shortness of breath. On presentation she had an exercise tolerance of 50 metres on the flat. She also complained of an exertional wheeze but had minimal cough. She was one of six children and

Correspondence: C. Jack, M.R.C.P., Cardiothoracic Centre, Broadgreen Hospital, Thomas Drive, Liverpool L14 3LB, UK

Accepted: 22 April 1991 none of her siblings had any history of lung disease. She was a life-long non-smoker.

On examination she was dyspnoeic, cyanosed $\vec{c}$ and thin. Cardiovascular system revealed evidence of pulmonary hypertension with a right ventricular $\stackrel{\mathbb{\Phi}}{\mathbb{D}}$ heave and palpable pulmonary second sound. She $\frac{3}{0}$ had a barrel shaped chest with widespread wheeze $\stackrel{\mathbb{D}}{-}$ on forced expiration. Investigations, including fa् 1 blood count and immunoglobulins, were norma blood gases revealed type I respiratory failuzi with a $\mathrm{PO}_{2}$ of $5.6 \mathrm{kPa}$. Her electrocardiograph showed $P$ pulmonale and her chest radiograph basal bullous emphysema (Figure 1). Full pulmonary function studies, including a flow volume $\frac{0}{\mathrm{D}}$ loop, were consistent with a diagnosis of $\varrho$ emphysema. The serum alpha-1-antitrypsin level $\overrightarrow{\overrightarrow{0}}$ was determined at $0.22 \mathrm{~g} / 1$ (normal range 3 $1.3-3.4 \mathrm{~g} / \mathrm{l})$ with a proteinase inhibitor $(\mathrm{Pi})$ phenotype piZZ.

\section{Case two}

A 65 year old retired chemist presented with a 10-year history of recurrent chest infections $\frac{O}{3}$ associated with a productive cough. He also com-

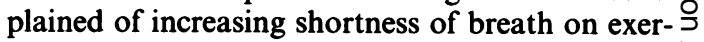
tion associated with wheeze. His past medical $\frac{7}{0}$ history and family history were unremarkable. He was a life-long non-smoker. The only positive $N_{\sigma}$ physical findings were coarse inspiratory crackles $N$ at the right base and widespread expiratory ${ }_{N}$ wheezes.

Investigations, including full blood count, immunoglobulins and electrocardiograph, were all $\stackrel{\circ}{\subset}$ normal; blood gases showed hypoxia $\mathrm{PO}_{2} 7.7 \mathrm{kPa}$ (on air). His chest radiograph revealed basal bul- lous emphysema. Spirometery showed a marked ${ }^{\circ}$ increase in the residual volume with a reduction in $\frac{\vec{D}}{0}$ 


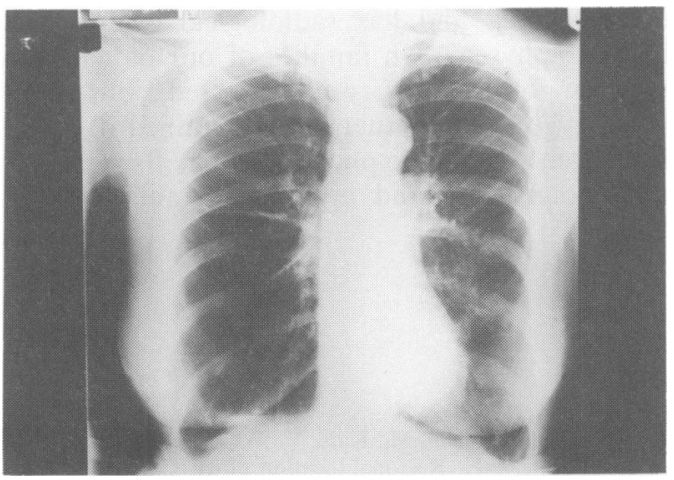

Figure 1 Chest X-ray showing basal bullous emphysema.

lung transfer factor in keeping with a diagnosis of emphysema. The flow volume loop showed the classical steeple curve of emphysema. The serum alpha-1-antitrypsin level was determined at $0.37 \mathrm{~g} / 1$, well below the normal range $(1.3-3.4 \mathrm{~g} / \mathrm{l})$, and the phenotype was PiSZ.

\section{Case three}

An 82-year old retired postman presented with a 3-year history of increasing shortness of breath on exertion. Exercise tolerance at presentation was 200 metres on the flat. He complained of a wheeze and was coughing about $20 \mathrm{ml}$ of clear sputum daily. He had undergone an intestinal resection in the past for suspected lymphoma and apart from an episode of pneumonia in 1988 he had remained well on no medication. He came from a large family with no history of lung disease. On examination there was no lymphadenopathy. The respiratory system revealed inspiratory crackles at the right base with widespread wheeze on expiration.

Investigations, including full blood count, immunoglobulins and electrocardiograph, were normal. Blood gases revealed hypoxia, his chest $\mathrm{X}$-ray showed basal bullous emphysema confirmed by full pulmonary function tests with a flow volume loop consistent with emphysema. The alpha-1antitrypsin level was $0.4 \mathrm{~g} / 1$ (normal range $1.3-3.4 \mathrm{~g} / \mathrm{l})$ with a phenotype PiZZ.

\section{Discussion}

Alpha-1-antitrypsin is a glycoprotein synthesized in the liver. It is an acute phase reactant ${ }^{2}$ and is a major proteinase inhibitor participating in many inflammatory processes occurring within the body. The clinical syndrome of alpha-1-antitrypsin deficiency was first observed in 5 subjects by
Laurell and Eriksson during routine analysis of electrophoretic strips. ${ }^{8}$ It is composed of 294 amino acids, ${ }^{9}$ with a molecular weight of 52000 and has a half life of 4-5 days in vivo.

The alpha-1-antitrypsin gene is a single gene of $12.2 \mathrm{~Kb}$, located as a pair of co-dominant autosomal alleles on chromosome 14 at $\mathrm{q} 31-32.3^{10-12}$ and is composed of 7 exons and 6 introns. ${ }^{13}$ It appears to be highly susceptible to genetic mutations which result in the formation of many variants and are readily classified by isoelectric focusing methods. These variants are most likely the result of single amino acid substitutions ${ }^{9}$ and only a few are clinically significant. Over $90 \%$ of the population show the proteinase inhibitor PiMM phenotype. Other clinically significant phenotypes include PiSS, PiSZ, PiZZ and Pinull null. These different phenotypes give rise to varying plasma levels of alpha-1-antitrypsin; thus PiZZ gives $15 \%$ of normal levels.

Alpha-1-antitrypsin is a ubiquitous enzyme but its greatest clinical importance is the protective effect on alveolar walls. By its nature, lung tissue is exposed to environmental factors predisposing to infection and inflammation. Alpha-1-antitrypsin is preferentially incorporated and remains active for longer periods of time in lung tissue compared to other body sites. The alveolar structure of the lungs is composed of elastin and other macro-molecules. These may be destroyed by neutrophil elastase resulting in emphysema. Alpha-1-antitrypsin prevents the function of neutrophil elastase by binding to it to produce an inactive complex ${ }^{14}$ and hence limiting parenchymal damage. Alveolar wall destruction occurs mainly at the bases in alpha-1antitrypsin deficiency. ${ }^{15}$ This is attributed to the higher blood flow in these basal segments and hence a greater concentration of polymorphs with the ability to release neutrophil elastase. ${ }^{16}$

In contrast, cigarette smokers develop apical emphysema. The currently accepted explanation for this distribution of alveolar wall destruction is the activation of pulmonary macrophages by irritants. ${ }^{16}$ Due to the ventilation/perfusion ratio in the lungs a greater number of macrophages are stimulated in the upper lobes and once activated they release neutrophil elastase, resulting in alveolar destruction. In alpha-1-antitrypsindeficient patients who are also cigarette smokers, the distribution of tissue damage is mainly basal. Cigarette smoking is the major contributing factor in both normal and alpha-1-antitrypsin deficient individuals. ${ }^{16,17}$ It is interesting to note that all our patients presented later in life and all were life-long non-smokers. This correlates with other previous studies. In a New Zealand study ${ }^{18}$ the average age for the onset of dyspnoea was 32 years in 14 cigarette smokers compared to 51 years in 8 non-smokers. In this study only $48 \%$ (33 out of 69 
patients) had clinical evidence of emphysema. In our small series the average age at presentation was 72 years and all of our patients had symptoms, signs, radiological and spirometric evidence of emphysema.

In conclusion, we believe that alpha-1-antitrypsin deficiency should be considered in any patient, regardless of their age, who presents with increas-

\section{References}

1. Larssen, C. Natural history and life expectancy in severe alpha-1-antitrypsin deficiency. Acta Med Scand 1987, 206: 345-351.

2. Aronsen, K.F., Ekelund, G., Kindmark, C.O. \& Laurell, C.-B. Sequential changes of plasma proteins after surgical trauma. Scand J Clin Lab Invest 1972, 29 (Suppl 124): 127-136.

3. Cox, D.W. \& Huber, P.O. Rheumatoid arthritis and alpha-1antitrypsin. Lancet 1977, i: 1216-1217.

4. Buisseret, P.D., Pembrey, M.E. \& Lessof, M.H. Alpha-1antitrypsin phenotypes in rheumatoid arthritis and ankylosing spondilitis. Lancet 1977, ii: 1358-1359.

5. Nicholls, M.G. \& Janus, E.D. Hashimoto's thyroiditis and homozygous alpha-1-antitrypsin deficiency. Aust $N \mathrm{Z} \mathrm{J} \mathrm{Med}$ 1973, 3: 516-519.

6. Lewis, M., Kallenbach, J., Zaltzman, M. et al. Severe deficiency of alpha-1-antitrypsin associated with cutaneous vasculitis, rapidly progressive glomerulonephritis, and colitis. Am J Med 1985, 79: 489-494.

7. Brewerton, D.A., Webley, M., Murphy, A.H. \& Milford Ward, A. The $\alpha_{1}$-antitrypsin phenotype $M Z$ in acute anterior uveitis. Lancet 1978, i: 1103 .

8. Laurell, C.-B. \& Eriksson, S. The electrophoretic $\alpha$-1-globulin pattern of serum $\alpha$-1-antitrypsin deficiency. Scand J Clin Lab Invest 1963, 15: 132-140.

9. Carrell, R.W., Jepsson, J.-O., Laurell, C.-B. et al. Structure and variation of human $\alpha$-1-antitrypsin. Nature 1982, 298: 329-334.

10. Long, G.L., Chandra, T., Woo, S.L.C., Davie, E.W. \& Kurachi, K. Complete sequence of the cDNA for human $\alpha 1$-antitrypsin and the gene for the s-variant. Biochemistry 1984, 23: 4828-4837. ing dyspnoea and has radiological evidence of $\stackrel{0}{\varrho}$ basal emphysema. In families of our patients no $\frac{3}{\infty}$ children or siblings were affected, but if $a \propto$ heterozygous spouse had been identified it would $ᄃ$ have been essential to phenotype the offspring and $\overrightarrow{\vec{F}}$ offer counselling and appropriate anti-smoking $\overrightarrow{0}$ advice.

11. Rabin, M., Watson, M., Kidd, V., Woo, S.L.C., Breg, W.R. $\vec{\exists}$ \& Ruddle, F.H. Regional location of $\alpha 1$-antichymotrypsin $\vec{\omega}$ and $\alpha 1$-antitrypsin genes on human chromosome 14. Somatic Cell Mol Genet 1986, 12: 209-214.

12. Perlino, E., Costese, R. \& Ciliberto, G. The human $\alpha 1-\underline{3}$ antitrypsin gene is transcribed from two different promoters in macrophages and hepatocytes. EMBO J 1987, 6: V 2767-2771.

13. Chan, S.K. \& Rees, D.C. Molecular basis for the $\alpha 1$-protease inhibitor deficiency. Nature 1975, 255: 240-241.

14. Morrison, H.M., Kramps, J.A., Afford, S.C. et al. Elastase + inhibitors in sputum from bronchitic patients with and without $\alpha$-1-proteinase inhibitor deficiency: partial charac- $J$ terisation of a hitherto unqualified inhibitor of neutrophil $\rightarrow$ elastase. Clin Sci 1987, 73: 19-28.

15. Gishen, P., Saunders, A.J.S., Tobin, M.J. et al. Alpha-1- $\frac{\mathbb{D}}{\mathrm{O}}$ antitrypsin deficiency: the radiological features of pulmonary $\vec{D}$ emphysema in subjects of Pi type $Z$ and Pi type SZ: a survey by the British Thoracic Association. Clin Radiol 1982, 33: 371-377.

16. Tobin, M.J., Duncan, C.S. \& Hutchinson, B.M. An overview $\vec{\theta}$ of the pulmonary features of $\alpha$-1-antitrypsin deficiency. Arch Intern Med 1982, 142: 1342-1348.

17. Eriksson, S. Studies in alpha-1-antitrypsin deficiency. Acta Med Scand 1965, 177 (Suppl 1): 1-85.

18. Janus, E.D., Phillips, N.T. \& Carrell, R.W. Smoking, lung function and $\alpha-1$-antitrypsin deficiency. Lancet 1985, i: $152-154$. 